\title{
Mandibular Condyle Depth Analysis in Magnetic Resonance of patients with temporomandibular disorders
}

\author{
Análisis de la Profundidad del Cóndilo Mandibular a través Resonancia \\ Magnética de Pacientes con Trastornos Temporomandibulares
}

Veronica Iturriaga ${ }^{1,2,3}$; Thomas Bornhardt ${ }^{1,2,3}$; Schilin Wen ${ }^{3,4}$; Marco Avila² \& Mariano del Sol $^{5}$

ITURRIAGA, V.; BORNHARDT, T.; WEN, S.; AVILA, M. \& DEL SOL, M. Mandibular condyle depth analysis in magnetic resonance of patients with temporomandibular disorders. Int. J. Morphol., 38(2):458-460, 2020.

SUMMARY: The study of the temporomandibular joint (TMJ) through imaging, is useful for the analysis of intra-articular procedures in view of its complex anatomy. Precise knowledge of the depth at which the TMJ is located is required to achieve an ideal puncture technique. The aim of this study was to measure the depth of the TMJ through magnetic resonance imaging (MRI) in patients with temporomandibular disorders (TMD). A cross-sectional study was conducted, selecting 150 MRI of patients who attended the Polyclinic for TMD and Orofacial Pain. The variables analyzed were: 1) Depth of the right and left TMJ; 2) Age of the patients; and 3) Sex of the patients. Of the total MR, 114 corresponded to women with a median age of 23 years. The median depth of the right TMJ was $17.16 \mathrm{~mm}$ and median on the left side was $16.98 \mathrm{~mm}$, there was no statistically significant difference ( $p>0.05)$ but there was a strong correlation $(r=0.842)$. There were no differences between the depths and the sex of the patients in both the right and left TMJ. There was no correlation between age and depth of TMJ. In conclusion the depth of the right and left condyle are highly correlated, being approximately $17 \mathrm{~mm}$ according to the population studied. There is no association between patient age and condylar depth, and there are no differences in average according to sex.

KEY WORDS: Temporomandibular joint; Temporomandibular joint disorders; Morphology; Magnetic resonance.

\section{INTRODUCTION}

The temporomandibular joint (TMJ) is a synovial joint with unique anatomical features (Gray \& Lewis, 2000). A precise description and knowledge of its anatomy is essential for clinical diagnosis of related pathological conditions and treatment planning (Brown et al., 2012; Matsumoto et al., 2014; Legemate et al., 2016; Xu et al., 2017).

Magnetic resonance imaging (MRI) is described as the standard imaging test for assessing soft tissues such as muscles, adipose tissue, ligaments and joint discs among others. It is useful both in static and dynamic position (López López et al., 2005), and has a specificity of $96 \%$ and a sensitivity of $98 \%$ (Bermejo, 1998).

According to literature reports, the location of the mandibular condyle (MC) in the sagittal plane presents great variability with respect to its position, indicating that the cen- tral position of the condyle-disc-fossa is not directly related to the presence of pathological conditions (Alves et al., 2014; Coombs et al., 2019; Fan et al., 2019). Temporomandibular disorders (TMD) are a group of pathologies that affect the TMJ, among which internal disorders may include, disc displacement and degenerative bone conditions, such as osteoarthritis. The use of minimally invasive techniques as corticosteroid injection, hyaluronic acid, or arthrocentesis, have been prescribed.

Due to its complex anatomy, TMJ imaging is particularly useful for intra-articular injection, providing accurate guidance for puncture site and to reduce possible complications such as a neurovascular injury, penetration of the mid-cranial cavity, or injury to the joint (Bjørnland et al., 1994; Sugisaki et al., 1995). In order to determine exact depth of the TMJ for the best puncture technique, detailed knowledge of the topographic anatomy is required.

\footnotetext{
${ }^{1}$ Department of Integral Adult Care Dentistry, Faculty of Dentistry, Universidad de La Frontera, Temuco, Chile.

${ }^{2}$ Temporomandibular Disorder and Orofacial Pain Program, Faculty of Dentistry, Universidad de La Frontera, Temuco, Chile.

${ }^{3}$ Sleep \& Pain Research Group, Universidad de La Frontera, Temuco, Chile.

${ }^{4}$ Doctoral Program in Morphological Sciences, Universidad de La Frontera, Temuco, Chile.

${ }^{5}$ Center of Excellence in Morphological and Surgical Studies (CEMyQ), Universidad de La Frontera, Temuco, Chile.

Funding: This research was supported by Temporomandibular Disorders and Orofacial Pain Program from Universidad de La Frontera and the Sleep \& Pain Research Group, Faculty of Dentistry, Universidad de La Frontera, Temuco, Chile.
} 
However, according to the evidence reviewed in this study, there is no reported record of this depth. Hence, the aim of this study was to measure the depth of the TMJ through magnetic resonance imaging (MRI) in patients with temporomandibular disorders (TMD).

\section{MATERIAL AND METHOD}

Design and ethical considerations. A cross-sectional study was carried out, randomly selecting 150 MR images of patients who attended the TMD and Orofacial Pain Polyclinic of the Dentistry Faculty, Universidad de La Frontera, Chile, from 2015 to 2018. This study followed Helsinski statement guidelines on medical and ethical protocols. All patients included in this study were anonymized and no data were obtained from their clinical records.

Variables studied. The variables analyzed were: 1) Depth of MC in the right and left TMJ; 2) Age of the patients; and 3) Sex of the patients. Depth of the MC was obtained by tracing a tangential line from the skin to the outermost area of the lateral pole of the MC, with frontal view of the TMJ; this distance was measured through the OsiriX® Program for MacOS, in T1 window. Patients' sex and age were obtained from the data recorded in each MR.

Statistical analysis. The Shapiro-Wilk Test was performed to contrast the normal distribution. For the analysis of descriptive statistics, central tendency measures were calculated. For the inferential analysis, the non-parametric Mann Whitney U test and the Pearson linear correlation coefficient (r) were used. The analyses were performed using the IBM / SPSS Statistics 20.0 MacOS software, considering a p-value less than 0.05 as significant.

\section{RESULTS}

In reference to the total MRI analyzed, 114 corresponded to women, median age of 23 years. The median MC depth of the right TMJ was $17.16 \mathrm{~mm}$ and left side median was $16.98 \mathrm{~mm}$. There was no statistically significant difference between the two ( $p>0.05)$, however, a strong correlation was noted $(\mathrm{r}=0.842)$.

There were no differences between the depths of the $\mathrm{MC}$ and the sex of the patients in both the right and left TMJ. There was also no correlation between the age of the patients and the depth of the MC.

\section{DISCUSSION}

In-depth knowledge TMJ anatomy is essential during diagnostic-therapeutic procedures such as intra-articular substance injection or arthrocentesis. Nowadays, these diagnostic tools are the methods of choice, given the advances in the understanding of intra-articular diseases, and the therapies available for these disorders. There has been important short and long-term development in this area, from a clinical point of view, as well as with the scientific evidence supporting the results.

MRI is considered a valuable tool, both during the diagnostic and therapeutic stages, as it allows identification of the soft structures of TMJ (Emshoff et al., 2002). Furthermore alterations in position and composition are the triggering factors for pathological conditions, with the ensuing painful symptoms and functional impairment. By assessing both soft and hard anatomical components through MRI, an anatomical analysis can be obtained, providing access and allowing minimally invasive clinical procedures with a greater degree of safety, thus reducing the risk of postoperative complications and improving therapeutic results.

Arthrocentesis technique consists of marking the insertion points of the needle (s) on the skin (McCain, 1988). The posterior entry point is located along the canto tragal line, $10 \mathrm{~mm}$ from the middle of the tragus, $2 \mathrm{~mm}$ below the line. The anterior entry point is located at a $10 \mathrm{~mm}$ distance along the line, and $10 \mathrm{~mm}$ below the line. These marks on the skin are the reference points that indicate the location of the joint cavity and articular eminence of the TMJ. There are other techniques involving the use of a needle, which underscores the relevance of thorough anatomical knowledge of the TMJ. However, morphology and position of the condyle may vary according to age and sex (Liu et al., 2018), the presence of certain pathologies (Santos et al., 2019), after orthodontic (Wang et al., 2018), or dentomaxilofacial orthopaedics treatments (Ghoussoub et al., 2018).

The aforementioned becomes vitally important when minimally invasive treatments are planned. These are carried out considering pathological conditions, alterations in anatomical characteristics and/or location of the intra-articular structures. In those cases, it is important to consider alteration of inter and intra articular pressure in cases of joint effusion, as these may change the position and relationship between condyle, cavity and joint disc.

In reference to these circumstances and whenever possible it becomes critical to know the exact anatomical 
location of joint structures prior to performing the various procedures. Since all minimally invasive procedures require intra-articular access, it is essential to have precise information as to anatomical depth at which the TMJ is expected to be found, in order to determine the proper choice of instruments and/or materials for treatment.

According to the literature researched, this is the first study reporting the depth of the mandibular condyle using MRI, evaluating the differences by sex, age or by right and left side, which provides important anatomical knowledge for the correct performance of minimally invasive intra-articular procedures. Furthermore, it is useful for the preferred choice of materials and equipment for these procedures, prompting fewer possible side-effects, procedural complications and possible surgical mishaps.

In conclusion, the depth of the right and left TMJ are highly correlated, being approximately $17 \mathrm{~mm}$ in the population studied. There is no association between patient age and condylar depth, and there are no differences in averages according to sex.

ITURRIAGA, V.; BORNHARDT, T.; WEN, S.; AVILA, M. \& DEL SOL, M. Análisis de la profundidad del cóndilo mandibular a través de resonancia magnética de pacientes con trastornos temporomandibulares. Int. J. Morphol., 38(2):458-460, 2020.

RESUMEN: El estudio por imágenes de la articulación temporomandibular (ATM) es útil para el análisis de procedimientos intra-articulares debido a la compleja anatomía que presenta. Se requiere un conocimiento preciso de la profundidad a la cual se encuentra la ATM para una adecuada técnica de punción. El objetivo de este estudio fue medir la profundidad de laATM en relación a la piel a través de resonancia magnética (RM) en pacientes con trastornos temporomandiblaes (TTM). Se realizó un estudio transversal, seleccionando 150 RM de pacientes que asistieron al Policlínico de TTM y Dolor Orofacial. La variables analizadas fueron: 1) Profundidad de la ATM derecha e izquierda; 2) Edad de los pacientes; y 3) Sexo de los pacientes. Del total de RM, 114 correspondían a mujeres con una mediana de edad de 23 años. La mediana de la profundidad de la ATM derecha fue de $17,16 \mathrm{~mm}$ y la mediana del lado izquierdo fue de $16,98 \mathrm{~mm}$, no hubo una diferencia estadísticamente significativa $(\mathrm{p}>0,05)$ pero si una fuerte correlación $(r=0,842)$. No hubo diferencias entre las profundidades y el sexo de los pacientes tanto en la ATM derecha como en la izquierda. No hubo correlación entre la edad y la profundidad de la ATM. La profundidad de los cóndilos derecho e izquierdo están altamente correlacionados, siendo $17 \mathrm{~mm}$ aproximadamente en la población estudiada. No existe asociación entre la edad de los pacientes y la profundidad condilar, y no hay diferencias en promedios por sexo.

PALABRAS CLAVE: Articulación temporo-mandibular; Trastornos de la articulución temporomandibular; Morfología; Resonancia magnetica.

\section{REFERENCES}

Alves, N.; Deana, N. F.; Schilling, Q. A.; González, V. A.; Schilling, L. J. \& Pastenes, R. C. Assessment of TMJ condylar position and joint space in Chilean individuals with temporomandibular disorders. Int. J. Morphol., 32(1):32-5, 2014

Bermejo, A. Medicina Bucal II. Enfermedades y Desórdenes Temporormandibulares. Dolor Orofacial y Manifestaciones Orales de Enfermedades Sistémicas. Madrid, Síntesis, 1998.

Bjørnland, T.; Rørvik, M.; Haanaes, H. R. \& Teige, J. Degenerative changes in the temporomandibular joint after diagnostic arthroscopy. An experimental study in goats. Int. J. Oral Maxillofac. Surg., 23(1):41-5, 1994.

Brown, B. N.; Chung, W. L.; Almarza, A. J.; Pavlick, M.; Reppas, S.; Ochs, M. W.; Russell, A. J. \& Badylak, S. F. An inductive, scaffold-based, regenerative medicine approach to reconstruction of the temporomandibular joint disk. J. Oral Maxillofac. Surg., 70(11):2656-68, 2012.

Coombs, M. C.; Bonthius, D. J.; Nie, X.; Lecholop, M. K.; Steed, M. B. \& Yao, H. Effect of measurement technique on TMJ mandibular condyle and articular disc morphometry: CBCT, MRI, and physical measurements. J. Oral Maxillofac. Surg., 77(1):42-53, 2019.

Emshoff, R.; Brandlmaier, I.; Bertram, S. \& Rudisch, A. Comparing methods for diagnosing temporomandibular joint disk displacement without reduction. $J$. Am. Dent. Assoc., 133(4):442-51, 2002.

Fan, W. P.; Liu, M. Q.; Zhang, X. H. \& Chen, Z. Y. MRI observation of condylar location and morphology in the patients with temporomandibular disc displacement. Zhonghua Kou Qiang Yi Xue Za Zhi, 54(8):522-6, 2019.

Ghoussoub, M. S.; Rifai, K.; Garcia, R. \& Sleilaty, G. Effect of rapid maxillary expansion on glenoid fossa and condyle-fossa relationship in growing patients (MEGP): study protocol for a controlled clinical trial. J. Int. Soc. Prev. Community Dent., 8(2):130-6, 2018.

Gray, H. \& Lewis, W. H. Anatomy of the Human Body. $20^{\text {th }}$ ed. New York, Bartleby, 2000 .

Legemate, K.; Tarafder, S.; Jun, Y. \& Lee, C. H. Engineering human TMJ discs with protein-releasing 3D-printed scaffolds. J. Dent. Res., 95(7):800-7, 2016.

Liu, Q.; Wei, X.; Guan, J.; Wang, R.; Zou, D. \& Yu, L. Assessment of condylar morphology and position using MSCT in an Asian population. Clin. Oral Investig., 22(7):2653-61, 2018.

López López, J.; Chimenos Küstner, E.; Blanco Carrión, A.; Reselló Llabrés, X. \& Jané Salass, E. Diagnóstico por la imagen de los trastornos de la articulación craneomandibular. Av. Odontoestomatol., 21(2):71-88, 2005.

Matsumoto, K.; Ishiduka, T.; Yamada, H.; Yonehara, Y.; Arai, Y. \& Honda, K. Clinical use of three-dimensional models of the temporomandibular joint established by rapid prototyping based on cone-beam computed tomography imaging data. Oral Radiol., 30(1):98-104, 2014.

McCain, T. P. Arthroscopy of the human temporomandibular joint. J. Oral Maxillofac. Surg., 46(8):648-55, 1988.

Santos, C. E. M.; Rodrigues, V. P.; De Oliveira, I. C. V.; De Assis, D. S. F. R.; De Oliveira, M. M. \& Conti, C. F. Morphological changes in the temporomandibular joints in women with fibromyalgia and myofascial pain: a case series. Cranio, 1-5, 2019. doi: 10.1080/08869634.2019.1650215. Online ahead of print.

Sugisaki, M.; Ikai, A. \& Tanabe, H. Dangerous angles and depths for middle ear and middle cranial fossa injury during arthroscopy of the temporomandibular joint. J. Oral Maxillofac. Surg., 53(7):803-10, 1995.

Wang, M. F.; Li, S. \& Liu, L. Influence on the condyle position by decreasing posterior occlusal plane angle in class II high angle cases. Shanghai Kou Qiang $Y i$ Хue, 27(4):386-9, 2018.

Xu, X.; Luo, D.; Guo, C. \& Rong, Q. A custom-made temporomandibular joint prosthesis for fabrication by selective laser melting: finite element analysis.Med. Eng. Phys., 46:1-11, 2017.

Corresponding author:

Dra. Veronica Iturriaga

Departamento de Odontología Integral Adulto

Facultad de Odontología

Universidad de La Frontera

Temuco - CHILE

Received: 08-08-2019

Accepted: 02-11-2019

Email: veronica.iturriaga@ufrontera.cl 